\title{
ЗАРУБЕЖНАЯ ИНФОРМАЦИЯ
}

\section{НАУЧНО-ИССЛЕДОВАТЕЛЬСКАЯ РАБОТА НА КАФЕДРЕ РАДИОФИЗИКИ НАНКИНСКОГО УНИВЕРСИТЕТА}

Қафедра раднофизики физического факультета Нанкинского университета была организована в июле 1956 г. В 1957 г. преподаватели кафедры читали студентам четвертого курса лекцин по дисциплинам: «Теория колебаний», «Электронно-вакуумные приборы СВЧ», «Электродинамика саптиметрового диапазона». Кроме того, для студентов младшего курса читался курс «Прикладная электроника».

После опубликования решений Компартин КНР о стронтельстве социализма в Китае, во время большого скачка в. промышленности и сельском хозяйстве, все члены нашей кафедры и студенты, изучая и внедряя решение Қомпартии о просвещении, ясно ссозналі, что просвсщение должио служить рабочему классу и сочетаться с про1!3водственным трудом. Все члены нашей кафедры участвуют в физнческом труде в мастерских при университете.

В настоящее время на нашей кафедре принята система последовательного преподавания, т. е. В данном промежутке времени читаются лекцин только одного курса (не считая политучебы и производственного труда). На кафедре сейчас организовано чтение курсов: «Микроволны», «Лампы СВЧ», «Теоретнческие основы радиотехники, «Электровакуумные приборы», «Электронные схемы» и организованы лаборатории по этим курсам.

На кафедре продолжается перестройка учебно-педагогической работы. в соответствии с реформой высшего образования КНР. Составляются: комплексный улебиый ллан, программы, учебные пособия и учебннки, улучшаются методы нашего пренодавания.

Главным направлением научно-исследовательской работы кафедры являются исследования в области СВЧ.

Предварительные результаты получены по следующим темам НИР:

a) Нсследование аптены с диаграммой направлености специальной формы (двойной косекансной). Математический анализ был выполнен на основе теории о распределении поля в раскрыве антенны. Результаты анализа хорошо совпадают с экспе. рнментальными данными, полученнымн руководнтелем кафедры Бо Зл-пен в 1944 г. в Массачузетском технологическом институте (США) п опубликованы в журнале «()нзика» (1952, 9, № 1), пздаваемом в КНР.

б) Теория распространения электромагиитной волин в ферритовой среде. Исследовалась задача о распространени электромагнитной волиы в цилиндрическом резонаторе с ферритовым стержнем или пластинкой и в ирямоугольном волноводе с пластинкой феррита вдоль широкой стешки (нормально вектору Е). Для указанных случаев определялись завнсимости резонансной частоты и фазовой постояниой от виешнего магнитного поля. Продолжается работа по упрощепно полученых формул.

в) Исследованне антешы с магнитиым качанием луча. В результатс раб́оты в сентябре 1958, г. было создано две аптенны: 1) волноводиая аптепна с магнитным качанем луча ири поперечном поле, обладающая углом качания главного лепестка диаграммы направленности $\pm 4^{\circ} ; 2$ ) рунорная антениа с магтитным качанием луча прн номоци продольного магинтного поля.

г) Нселедованне эффекта Фарадея. Для опытов иами был изготовлеи феррит $\mathrm{Mg} \rightarrow \mathrm{Mn}$, с помоццю которого можно получить поворот плоскості поляризацин $67^{\circ} / \mathrm{cs}^{3}$ nрни внешнем магнитном поле в $1302 c$.

д) Нелинійая теория ферромагнетизма на оспове смецения стенок доменов. Результаты анализа, опуо́ликованные в № 3 Информационног физнческого журнала (КНР) за 1958 г., позволио' дать объяснение экспернменталыным даным, полученим Rado c Fe-Mg ферритами.

е) Исследование параметров усилителя с распределеными параметрами на основе теорни фильтров.

Используемые в НИР ферриты изготовлялись прешоданателями кафедры магиетизма пашего университета. Некоторые работы выполиены совместио кафедрами раднофнзики и магнетизма.

До 1958 г. больниство паучно-нсследовательских работ выполиялось студентами-дипломантами под руководством ирофессоров, темы нсследований не планировались и не были тесно увязаны с требованиями промышлениости. Госле опубликования 
решений о политике Компартии КНР в области просвещения коллектив кафедры резко перестроил организацию научно-исследовательской работы.

В настояцее время все преподаватели кафедры и студенты старших курсов приинмают участие в НИР, связанной с промышленностью, по следующей тематнке: a) антенна с магнитным качаннем луча; б) ферритовый усилитель; в) автоуправление трактором; г) электронный микроскоп; д) радиотелескоп.

Совмсщая учебные занятия с полезным трудом, преподаватели и студенты изготовнли собствениыми силами ряд приборов для наших лабораторий.

Большую помоць кафедре с сентября 1958 г. оказывает советский специалист Н. Т. Бова (доцент Киевского политехнического института), чнтая лекцин для молодых прелодавателей вузов КНР по аптеннам СВЧ, помогая в организации лабораторни и научно-гсследовательской работе.

$\mathrm{B}$ связи с потребностыо в специалистах по радиофнзике на кафедре вводятся курсы: «Техника СВЧ», «Электронные схемы» и «Электронная физика».

Перед коллективом нашей кафедры стоят сложные и ответственные задачіг. Члены кафедры с уверенностью и большой энергней выполняют учебно-педагогическую и научно-исследовательскую работу, испытывая уверенность, что под руководством Компартин ҚНР и при помощи Советского Союза преодолеют все трудности и подготовят преданных Родине квалифицированных радиофизиков.

Қоллектив нашей кафедры пользуется случаем выразить желание установнть тесную связь и сотрудннчество с кафедрами радиофизики и радиотехническими факультетами вузов СССР, что поможет ускорить темпы строительства соцналюзма B KHP.

30 IV $1959 \mathrm{r}$.
Зав. кафедрой радиофизики физического факультета Нанкинского университета профессор Бо Зя-шен 